\title{
Detection of Phosphine Resistance in Field Populations of Four Key Stored-Grain Insect Pests in Pakistan
}

\author{
Waqas Wakil ${ }^{1, *(\mathbb{C})}$, Nickolas G. Kavallieratos ${ }^{2, *} \mathbb{B}$, Muhammad Usman ${ }^{1}{ }^{\mathbb{C}}$, Sehrish Gulzar ${ }^{1}$ \\ and Hamadttu A. F. El-Shafie ${ }^{3}$ (D) \\ 1 Department of Entomology, University of Agriculture, Faisalabad 38040, Pakistan; \\ usmanbhattiuaf@gmail.com (M.U.); sehrishgulzar41@gmail.com (S.G.) \\ 2 Laboratory of Agricultural Zoology and Entomology, Department of Crop Science, Agricultural University of \\ Athens, 75 Iera Odos str., 11855 Athens, Greece \\ 3 Date Palm Research Center of Excellence, King Faisal University, Hofuf, Al-Ahsa 31982, Saudi Arabia; \\ elshafie62@yahoo.com \\ * Correspondence: waqaswakeel@hotmail.com (W.W.); nick_kaval@aua.gr (N.G.K.); \\ Tel.: +92-419200161-70 (W.W.); +30-2105294569 (N.G.K.)
}

Citation: Wakil, W.; Kavallieratos, N.G.; Usman, M.; Gulzar, S.; El-Shafie, H.A.F. Detection of Phosphine Resistance in Field Populations of Four Key Stored-Grain Insect Pests in Pakistan. Insects 2021, 12, 288. https://doi.org/10.3390/insects 12040288

Academic Editor: David Schlipalius

Received: 4 March 2021

Accepted: 22 March 2021

Published: 26 March 2021

Publisher's Note: MDPI stays neutral with regard to jurisdictional claims in published maps and institutional affiliations.

Copyright: (c) 2021 by the authors. Licensee MDPI, Basel, Switzerland. This article is an open access article distributed under the terms and conditions of the Creative Commons Attribution (CC BY) license (https:// creativecommons.org/licenses/by/ $4.0 /)$.
Simple Summary: The resistance of coleopteran stored-product pests to phosphine fumigation is becoming a global phenomenon. However, there is limited literature available and a lack of knowledge on this issue in Pakistan. Thus, in the current study, we estimated the status of phosphine resistance among ten populations of Rhyzopertha dominica (F.) (Coleoptera: Bostrychidae), Sitophilus granarius (L.) (Coleoptera: Curculionidae), Tribolium castaneum (Herbst) (Coleoptera: Tenebrionidae) and Trogoderma granarium Everts (Coleoptera: Dermestidae), originated from different regions of Pakistan. Laboratory-susceptible populations of all insect species were also considered in the tests. Concentration-response bioassays were conducted for each insect species. All of the tested populations of each species were found to be resistant to phosphine. However, they varied with regard to their levels of resistance. Overall, $R$. dominica exhibited the highest resistance level, followed by T. castaneum, T. granarium and S. granarius. Although phosphine is effective against several stored-product pests, the development of resistance may lead to failures in its application in Pakistan.

Abstract: In Pakistan, the control of stored-product insect pests mainly relies on the use of phosphine gas along with other control tactics. The aim of this study was to determine the level of phosphine resistance among ten differently located populations of the lesser grain borer, Rhyzopertha dominica (F.) (Coleoptera: Bostrychidae), the granary weevil, Sitophilus granarius (L.) (Coleoptera: Curculionidae), the red flour beetle, Tribolium castaneum (Herbst) (Coleoptera: Tenebrionidae) and the khapra beetle, Trogoderma granarium Everts (Coleoptera: Dermestidae). Laboratory-susceptible populations of all insect species were also considered in the experiments. Concentration-response bioassays were conducted for each species. All of the tested populations (10 out of 10) of each species were found to be resistant to phosphine, but varied in their level of resistance. Probit analysis estimated $\mathrm{LC}_{50}$ at 2.85, 1.90, 2.54 and 2.01 ppm for laboratory-susceptible populations of R. dominica, S. granarius, $T$. castaneum and T. granarium, respectively. Against $R$. dominica, the highest and lowest resistance levels were observed in the Rahim Yar Khan $\left(\mathrm{LC}_{50}\right.$ at $\left.360.90 \mathrm{ppm}\right)$ and Rawalpindi ( $\mathrm{LC}_{50}$ at $\left.210.98 \mathrm{ppm}\right)$ populations, respectively. These resistant populations were 126.67- and 74.02-fold more resistant than the laboratory population. The Multan and Lahore populations of $S$. granarius exhibited the maximum ( $\mathrm{LC}_{50}$ at $122.81 \mathrm{ppm}$ ) and minimum $\left(\mathrm{LC}_{50}\right.$ at $\left.45.96 \mathrm{ppm}\right)$ resistance levels, respectively, i.e., they were 64.63- and 24.18-fold more resistant than the laboratory population. The Layyah population of T. castaneum showed the maximum resistance level ( $\mathrm{LC}_{50}$ at $305.89 \mathrm{ppm}$ ) while the lowest was observed in the Lahore population ( $\mathrm{LC}_{50}$ at $\left.186.52 \mathrm{ppm}\right)$, corresponding to 120.42- and 73.43-fold more resistant than the laboratory population, respectively. Regarding T. granarium, the Layyah population showed the maximum resistance level ( $\mathrm{LC}_{50}$ at $169.99 \mathrm{ppm}$ ) while the Lahore population showed the minimum resistance ( $\mathrm{LC}_{50}$ at $74.50 \mathrm{ppm}$ ), i.e., they were 84.57 - and 37.06 -fold more resistant than the laboratory population, respectively. Overall, $R$. dominica presented the highest resistance level, followed by T. castaneum, T. granarium and S. granarius. The current study suggests 
that the application of phosphine may not be an adequate control strategy for the management of the above tested insect pests in Pakistan.

Keywords: lesser grain borer; granary weevil; red flour beetle; khapra beetle; phosphine; resistance level

\section{Introduction}

Control tactics applied in grain commodities before storage include the removal of grain debris and the application of insecticides [1]. Although synthetic insecticides act as efficient management tools that provide quick control of insect pests, they can have negative impact on humans' health and the environment [2,3]. The overuse or improper use of insecticides may trigger the development of resistance to insecticides [4]. Specifically, due to heavy exposure to chemical insecticides, stored-grain insects have developed resistance to major classes of insecticides, e.g., pyrethroids and organophosphates [5-8]. Resistance to certain chemical insecticides, such as fenitrothion, pirimiphos-methyl and malathion, has been investigated in the lesser grain borer, Rhyzopertha dominica (F.) (Coleoptera: Bostrychidae), the rice weevil, Sitophilus oryzae (L.) (Coleoptera: Curculionidae), the red flour beetle, Tribolium castaneum (Herbst) (Coleoptera: Tenebrionidae) and the maize weevil, Sitophilus zeamais Motschulsky (Coleoptera: Curculionidae) [9,10]. Cases of resistance to pyrethroids have been recorded in the last two decades in S. zeamais [11-14]. The extensive spread of resistant populations of $S$. zeamais through grain trade within Brazil has been identified as the main issue leading to the development of insecticidal resistance [12,14]. Perez Medoza [15] also observed resistance to permethrin and deltamethrin in Mexican strains of S. oryzae. In Australia, the saw-toothed grain beetle, Oryzaephilus surinamensis (L.) (Coleoptera: Silvanidae), was found to be resistant to frequently used insecticides (e.g., chlorpyrifos-methyl, pirimiphos-methyl and fenitrothion) [16].

Fumigation with phosphine is widely used as an important method of protection of stored commodities against different insect pests. It is inexpensive, has fewer residual effects than contact insecticides, is easily applicable and represents an ideal fumigant gas that can be applied to a wide range of stored commodities and structures (e.g., warehouses, silos, bag stacks, bunkers, cereal mills and ships during transport) [17-21]. Additionally, phosphine has been globally trusted as a food-safe and residue-free treatment for stored grains [22]. However, the repeated use of this fumigant in storage facilities has led to the development of phosphine resistance in major stored-grain insect species [23].

During the 1970s, Champ and Dyte [24] conducted the first global survey related to phosphine resistance and documented that several main stored-grain insect pests exhibited phosphine resistance across different countries [23]. Previous studies have documented the absence, and presence, of phosphine resistance in populations of pests and revealed additional information about the existence of two phenotypes of resistance (strong and weak) in insect individuals [23,25-28]. The weak and strong resistance phenotypes are associated with 10- to 50 -fold and $\geq 100$-fold higher concentrations of phosphine, respectively, than the concentrations reported to be needed to suppress susceptible insects in the cases of the rusty grain beetle, Cryptolestes ferrugineus (Stephens) (Coleoptera: Laemophloeidae), $R$. dominica, S. oryzae and T. castaneum $[22,29,30]$. Recent studies confirmed the high incidence of phosphine resistance in major stored-grain pests at various locations around the world [25-27,31-33]. Opit et al. [26] determined that the resistance frequencies in $T$. castaneum and $R$. dominica were considerably higher than those found twenty years earlier at the same sites studied by Zettler and Cuperus [34]. More recent studies in North America reported that almost half of 25 studied T. castaneum populations exhibited phosphine resistance [35], while 4 out of 14 populations of adults and 9 out of 14 populations of eggs of $O$. surinamensis were also resistant to this fumigant [33]. 
Rhyzopertha dominica, the granary weevil, Sitophilus granarius (L.) (Coleoptera: Curculionidae) and T. castaneum cause considerable damage to numerous types of stored commodities in food warehouses, cereal-processing facilities and retail stores worldwide [36-40]. The khapra beetle, Trogoderma granarium Everts (Coleoptera: Dermestidae), is an extremely dangerous invasive pest of stored products of plant and animal origin [41-44]. It exists in Asia, Europe and Africa, but has also been intercepted in the USA and Australia $[45,46]$. Currently, it is categorized as a quarantine pest in Belarus, Canada, Mexico, Morocco, New Zealand, the USA and other countries [46]. Rhyzopertha dominica, S. granarius and $T$. granarium are primary feeders, i.e., they can easily damage whole kernels, while T. castaneum is a secondary feeder, i.e., it mostly prefers damaged, either mechanically or by the activity of primary pests, kernels [36]. Trogoderma granarium larvae accelerate the damage of sound kernels when 10-25\% cracked kernels are present [47]. Despite the fact that the aforementioned pests are present in Pakistan [48-50], there is limited knowledge regarding their resistance to phosphine. For example, Ahmedani et al. [51] assessed two populations of $T$. granarium from just one district of Pakistan to detect their level of phosphine resistance. Therefore, the objective of the current study was to determine the level of phosphine resistance among differently geographically distributed populations of $R$. dominica, S. granarius, T. castaneum and T. granarium in Pakistan.

\section{Materials and Methods}

\subsection{Test Insect Populations}

Wheat-grain samples were collected from wheat-storage structures of ten different geographical regions of Pakistan, i.e., Sargodha, Multan, Faisalabad, Bahawalpur, Rawalpindi, Layyah, Lahore, Rahim Yar Khan, Jhang and Gujranwala (Figure 1). Six storage facilities were sampled per area. Within each storage facility, quantities of $500 \mathrm{~g}$ of wheat were taken from 5 different points. The wheat samples were mixed to make a new sample of $2.5 \mathrm{~kg}$ that was put inside a zip lock bag and transferred to the laboratory. The samples were sieved to separate the insects [52]. The collected $R$. dominica, S. granarius, T. granarium and $T$. castaneum adults were identified. The numbers of the collected insects ranged between 45 and 230 individuals per species and were used to start cultures. All species were cultured for at least seven generations in order to produce enough individuals for the experiments [26]. The laboratory strains of these insect pests were obtained from the Microbial Control Laboratory in the Department of Entomology, University of Agriculture, Faisalabad, Pakistan. The laboratory population had been reared for more than 10 years without being exposed to any chemical insecticides, including phosphine. Sitophilus granarius and $R$. dominica were reared on wheat at $25^{\circ} \mathrm{C}$, in $65 \%$ relative humidity, in complete darkness. Trogoderma granarium was maintained on wheat at $30{ }^{\circ} \mathrm{C}$, in $65 \%$ relative humidity, in complete darkness. Tribolium castaneum was cultured on wheat flour with $5 \%$ brewer's yeast at $25^{\circ} \mathrm{C}$, in $65 \%$ relative humidity, in complete darkness.

\subsection{Phosphine Gas Generation}

The phosphine gas was generated using the Food and Agriculture Organization of the United Nations (FAO) protocol [53]. The apparatus used for the phosphine generation included a beaker with $5 \mathrm{~L}$ capacity, an aluminum phosphide tablet, a collection tube (cylinder), an inverted funnel and muslin cloth. One side of the collection tube was sealed with an airtight rubber stopper that was filled with a $5 \%$ solution of $\mathrm{H}_{2} \mathrm{SO}_{4}$. Additionally, half of the beaker was filled with a $5 \%$ solution of $\mathrm{H}_{2} \mathrm{SO}_{4}$. The collection tube was carefully placed on the beaker, over the inverted funnel, without any loss of $\mathrm{H}_{2} \mathrm{SO}_{4}$ from the collecting tube. Before the generation of phosphine gas, all of the air was removed from the collecting tube using a syringe. The aluminum phosphide tablet was carefully wrapped with muslin cloth and put under the inverted funnel. The phosphine gas was collected in the collection tube on the underside of the inverted funnel. As the funnel filled with gas, the solution level of $\mathrm{H}_{2} \mathrm{SO}_{4}$ decreased. When the collection tube was filled with gas, a volume of $5 \mathrm{~mL}$ was taken with an airtight syringe and injected into the sealed desiccators. Then, $50 \mathrm{~mL}$ of 
gas were taken from the desiccators and injected into a phosphine meter to measure its concentration (Silo Check Phosphine Monitor, The Canary Company Pty. Ltd., Lane Cove, NSW, Australia).

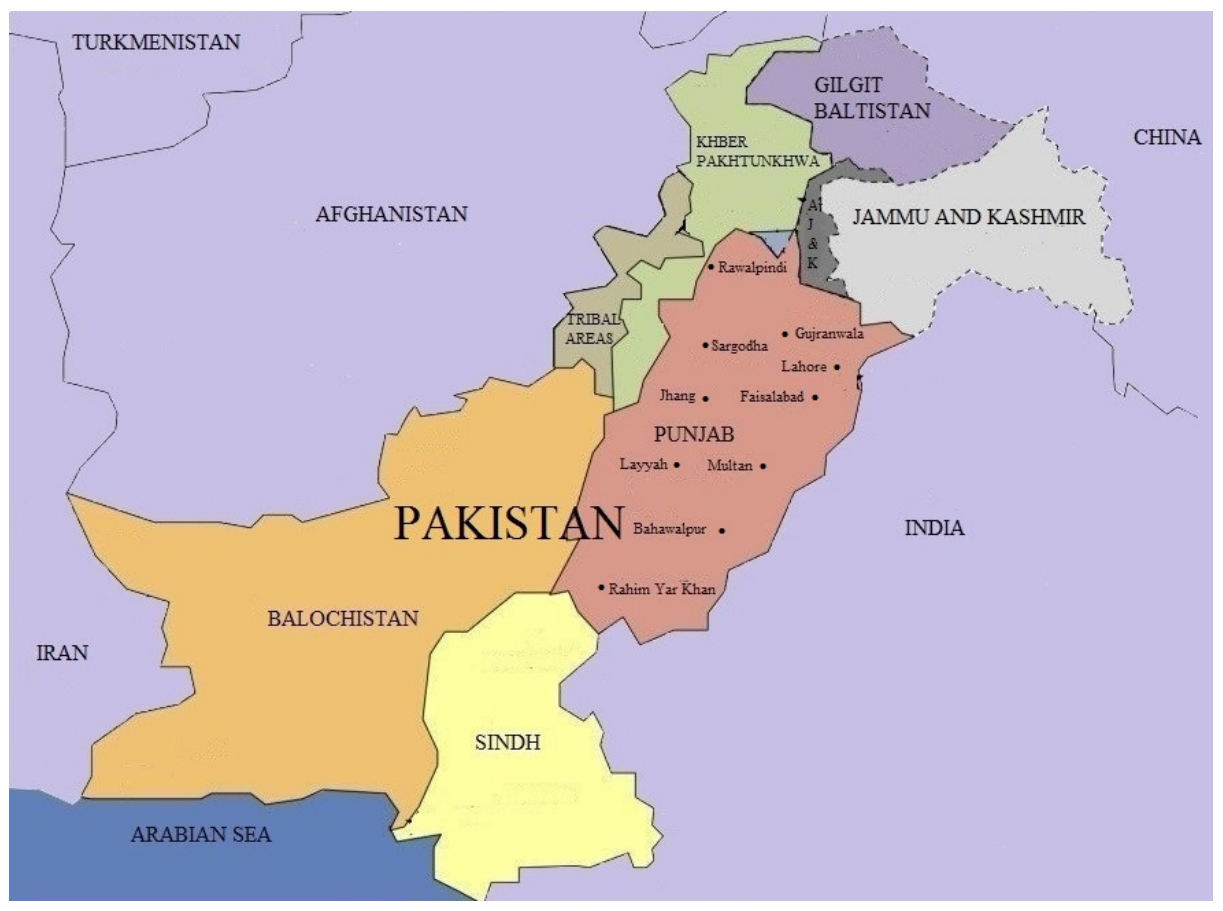

Figure 1. Map of Pakistan showing the regions of origin for the ten sampled populations of Rhyzopertha dominica, Sitophilus granarius, Tribolium castaneum and Trogoderma granarium tested for phosphine resistance.

\subsection{Bioassays}

For monitoring of resistance among different stored-grain insect pests, FAO method No. 16 [53] was followed. Adult R. dominica, S. granarius or T. castaneum (less than two weeks old) and adult $T$. granarium (less than $24 \mathrm{~h}$ old), of mixed-sex ratios, were used in the tests. From each field and laboratory insect population, 50 adult individuals were separately put in 4 glass vials $(1.2 \mathrm{~cm}$ in diameter by $4.5 \mathrm{~cm}$ in height). The four glass vials (with one vial representing one species from one location) were grouped together with a rubber band and similar vials were prepared for the rest of the nine populations and placed in a $3.8 \mathrm{~L}$ glass jar prior to the introduction of phosphine gas (50 individuals of each species per vial $\times 4$ species $(=200$ adults per location $) \times 10$ locations $=2000$ individuals per jar). Seven concentrations (50, 100, 200, 300, 400, 500 and 600 ppm) of phosphine were used for the field populations and each concentration within one jar represents one treatment. There were 40 vials in one jar and a total seven jars for seven concentrations. Each insect species of the laboratory populations was exposed to seven $(1,2,3,6,9,12$ and $15 \mathrm{ppm}$ ) phosphine concentrations. Thus, there were four vials in a single jar. Lower concentrations of phosphine were tested in the case of laboratory populations since they are highly susceptible to chemical insecticides. For each location, the same number of adults was placed inside vials in a single jar, without any treatment, to serve as controls. These vials were covered with muslin cloth and wrapped at the top with a rubber band. The muslin cloth promoted the entry of phosphine gas into the vials and also restricted the escape of insects. A small quantity of diet $(0.5 \mathrm{~g}$ wheat $)$ was added into each vial. The airtight jar served as a fumigation chamber with a metal screw lid at the center, equipped with a port connected to a rubber injection septum for the entrance and sampling of phosphine gas. Before the lid was screwed onto the jar, a rubber gasket was fitted inside it and a thin layer of vacuum grease was applied to the seal between the metal lid and the top 
of the edges of the jars to ensure the chamber was gas-tight. The gas was introduced into the jars through the rubber septum with the help of a gas-tight syringe, after removing an equal amount of air with the syringe. The maintenance of a relative humidity of up to $70 \%$ was achieved via the addition of two drops of water inside the jar. The jars were maintained inside a chamber at $25^{\circ} \mathrm{C}$ for the bioassay. Twenty hours later, all vials were removed from the jars and were kept at $25{ }^{\circ} \mathrm{C}$, in $70 \%$ relative humidity. Seven days post-application, all insects in the vials were counted and classified as live or dead [54]. Dead individuals were placed inside Petri dishes lined with filter paper, which was previously moistened with $0.5 \mathrm{~mL}$ of distilled water [26]. These individuals were inspected again after $24 \mathrm{~h}$ for possible recoveries. Each treatment (phosphine concentration) included 21 jars (7 treatment jars $\times 3$ replications). The whole experiment was conducted twice by preparing new vials, wheat diet and insects each time (six replications totally).

\subsection{Statistical Analyses}

Mortality in controls was corrected using Abbott's [55] formula, which was $<5 \%$ for all species [28,54]. Data were analyzed using PROC PROBIT from SAS version 9.1 [56]. Lethal concentrations including $\mathrm{LC}_{50}$ and $95 \%$ fiducial limits were determined for each tested population from each location. Resistance ratios (RRs) were assessed by dividing the $\mathrm{LC}_{50}$ values of tested insecticides by their respective susceptible population.

\section{Results}

\subsection{Resistance in R. dominica}

The current study revealed that all tested populations collected from different geographical regions were found to be resistant to phosphine with reference to the laboratory population. However, the tested populations exhibited variable levels of resistance to phosphine. Probit analysis estimated that the $\mathrm{LC}_{50}$ for the laboratory population was $2.85 \mathrm{ppm}$. The Rahim Yar Khan population was the most resistant with $\mathrm{LC}_{50}$ at $360.90 \mathrm{ppm}$, i.e., it was 126.67-fold more resistant than the laboratory population. The population with the lowest resistance was obtained from Rawalpindi with $\mathrm{LC}_{50}$ at $210.98 \mathrm{ppm}$, i.e., it was 74.02 -fold more resistant when compared with the laboratory population. For all other cases, $\mathrm{LC}_{50}$ ranged between 234.05 and 333.37, i.e., an 82.12- and 116.97-fold higher resistance than the laboratory population, in Lahore and Multan, respectively (Table 1).

Table 1. Probit analysis of mortality for 10 field-collected populations and a laboratory-susceptible population of Rhyzopertha dominica adults after $20 \mathrm{~h}$ of exposure to phosphine. In all cases DF $=5$.

\begin{tabular}{ccccccc}
\hline Region & LC $_{\mathbf{5 0}}(\mathbf{p p m}) \mathbf{9 5} \% \mathbf{F L}$ & Slope & Chi-Square & $p$ & Intercept $^{\text {R }} \mathbf{R}^{\mathbf{a}}$ \\
\hline Sargodha & $236.32(163.06-259.16)$ & $2.35 \pm 0.99$ & 78.38 & $<0.01$ & $-6.79 \pm 1.58$ \\
Multan & $333.37(112.01-415.37)$ & $3.02 \pm 0.92$ & 36.57 & $<0.01$ & $-7.63 \pm 1.45$ & 82.91 \\
Faisalabad & $257.99(23.21-342.38)$ & $2.42 \pm 0.76$ & 71.85 & $<0.01$ & $-21.37 \pm 1.98$ & 90.52 \\
Bahawalpur & $295.83(215.23-376.28)$ & $2.89 \pm 1.47$ & 53.86 & $<0.01$ & $-7.15 \pm 1.90$ & 103.80 \\
Rawalpindi & $210.98(163.06-259.16)$ & $2.28 \pm 0.25$ & 26.76 & $<0.01$ & $-5.31 \pm 0.62$ & 74.02 \\
Layyah & $287.72(173.37-357.61)$ & $2.73 \pm 0.86$ & 62.93 & $<0.01$ & $-6.72 \pm 1.82$ & 100.95 \\
Lahore & $234.05(186.14-309.39)$ & $2.96 \pm 0.13$ & 57.91 & $<0.01$ & $-7.01 \pm 1.96$ & 82.12 \\
Rahim Yar Khan & $360.90(98.92-441.17)$ & $4.19 \pm 0.58$ & 46.22 & $<0.01$ & $-11.09 \pm 1.12$ & 126.67 \\
Jhang & $315.36(206.20-381.26)$ & $2.90 \pm 1.19$ & 47.00 & $<0.01$ & $-7.25 \pm 1.16$ & 110.65 \\
Gujranwala & $279.88(171.28-416.52)$ & $3.31 \pm 0.56$ & 78.31 & $<0.01$ & $-8.10 \pm 1.21$ & 98.20 \\
Laboratory & $2.85(2.62-3.07)$ & $2.48 \pm 0.10$ & 7.44 & 0.18 & $-1.13 \pm 0.07$ & - \\
\hline
\end{tabular}

LC: lethal concentration; FL: fiducial limits; RR: resistance ratio; ${ }^{\text {a }}$ RR = LC50-resistant population/LC50-susceptible population.

\subsection{Resistance in S. granarius}

The populations of $S$. granarius that were collected from different geographical regions exhibited resistance to phosphine with reference to the laboratory-susceptible population. Although all of the test populations were found to be resistant to phosphine, they showed variable levels of resistance. Probit analysis evaluated the $\mathrm{LC}_{50}$ for the laboratory population at $1.90 \mathrm{ppm}$. The Multan population was the most resistant population with $\mathrm{LC}_{50}$ 
at $122.81 \mathrm{ppm}$, i.e., it was 64.63 -fold more resistant when compared with the laboratory population, followed by the Jhang, Layyah and Bahawalpur populations, having $\mathrm{LC}_{50}$ values of $119.37,107.29$ and $93.72 \mathrm{ppm}$, i.e., they were $62.82-, 56.46$ - and 49.32 -fold more resistant than the laboratory population, respectively (Table 2).

Table 2. Probit analysis of mortality for 10 field-collected populations and a laboratory-susceptible population of Sitophilus granarius adults after $20 \mathrm{~h}$ of exposure to phosphine. In all cases DF $=5$.

\begin{tabular}{|c|c|c|c|c|c|c|}
\hline Region & $\mathrm{LC}_{50}(\mathrm{ppm}) 95 \% \mathrm{FL}$ & Slope & Chi-Square & $p$ & Intercept & $\mathbf{R R}^{\mathbf{a}}$ \\
\hline Sargodha & $86.60(69.64-103.03)$ & $2.20 \pm 0.15$ & 11.05 & 0.05 & $-4.26 \pm 0.34$ & 45.57 \\
\hline Multan & $122.81(89.15-155.13)$ & $2.31 \pm 0.24$ & 26.55 & $<0.01$ & $-4.82 \pm 0.56$ & 64.63 \\
\hline Faisalabad & $71.26(54.62-87.26)$ & $2.10 \pm 0.15$ & 11.85 & 0.03 & $-3.90 \pm 0.35$ & 37.50 \\
\hline Bahawalpur & 93.72 (75.20-111.68) & $2.15 \pm 0.14$ & 11.29 & 0.04 & $-4.25 \pm 0.34$ & 49.32 \\
\hline Rawalpindi & $48.58(27.28-68.61)$ & $2.03 \pm 0.25$ & 25.18 & $<0.01$ & $-3.43 \pm 0.54$ & 25.56 \\
\hline Layyah & $107.29(81.23-132.49)$ & $2.33 \pm 0.21$ & 21.74 & $<0.01$ & $-4.73 \pm 0.49$ & 56.46 \\
\hline Lahore & $45.96(28.55-62.43)$ & $2.06 \pm 0.21$ & 18.07 & $<0.01$ & $-3.42 \pm 0.47$ & 24.18 \\
\hline Rahim Yar Khan & $63.17(44.80-80.62)$ & $2.19 \pm 0.20$ & 16.79 & $<0.01$ & $-3.95 \pm 0.442$ & 33.24 \\
\hline Jhang & $119.37(84.69-152.65)$ & $2.25 \pm 0.24$ & 28.55 & $<0.01$ & $-4.68 \pm 0.57$ & 62.82 \\
\hline Gujranwala & $66.75(60.94-80.96)$ & $2.11 \pm 0.14$ & 9.92 & 0.07 & $-3.85 \pm 0.32$ & 35.13 \\
\hline Laboratory & $1.90(1.51-2.28)$ & $2.21 \pm 0.16$ & 12.23 & 0.03 & $-0.61 \pm 0.10$ & - \\
\hline
\end{tabular}

LC: lethal concentration; FL: fiducial limits; RR: resistance ratio; ${ }^{a}$ RR = LC50-resistant population/LC50-susceptible population.

\subsection{Resistance in T. castaneum}

The tested T. castaneum populations were resistant to phosphine in relation to the laboratory population. Probit analysis revealed that the $\mathrm{LC}_{50}$ was $2.54 \mathrm{ppm}$ for the laboratory population. Of the different populations, those from Layyah and Lahore showed the highest and lowest resistance levels with $\mathrm{LC}_{50}$ values of 305.89 and $186.52 \mathrm{ppm}$, i.e., they were 120.42- and 73.43-fold more resistant when compared with the laboratory population, respectively. The $\mathrm{LC}_{50}$ levels of all other tested populations ranged between 202.99 (Faisalabad) and 275.91 ppm (Jhang), i.e., between 79.91- and 108.62-fold more resistant compared with the laboratory population (Table 3 ).

Table 3. Probit analysis of mortality for 10 field-collected populations and a laboratory-susceptible population of Tribolium castaneum adults after $20 \mathrm{~h}$ of exposure to phosphine. In all cases DF $=5$.

\begin{tabular}{ccccccc}
\hline Region & LC $_{\mathbf{5 0}}(\mathbf{p p m}) \mathbf{9 5} \mathbf{5} \mathbf{~ F L}$ & Slope & Chi-Square & $p$ & Intercept $^{\mathbf{a}}$ & $\mathbf{R R}^{\mathbf{a}}$ \\
\hline Sargodha & $223.06(156.78-298.67)$ & $3.79 \pm 0.54$ & 79.47 & $<0.01$ & $-8.91 \pm 1.97$ & 87.81 \\
Multan & $261.00(24.62-343.96)$ & $3.38 \pm 1.10$ & 54.30 & $<0.01$ & $-8.16 \pm 1.88$ & 102.75 \\
Faisalabad & $202.99(113.75-260.90)$ & $2.75 \pm 0.73$ & 89.89 & $<0.01$ & $-6.36 \pm 1.51$ & 79.91 \\
Bahawalpur & $245.43(66.41-341.11)$ & $3.17 \pm 0.99$ & 48.54 & $<0.01$ & $-7.59 \pm 1.71$ & 96.62 \\
Rawalpindi & $234.63(141.27-289.47)$ & $3.26 \pm 1.29$ & 67.19 & $<0.01$ & $-7.41 \pm 1.36$ & 92.37 \\
Layyah & $305.89(131.04-374.82)$ & $3.73 \pm 1.04$ & 41.34 & $<0.01$ & $-9.27 \pm 1.72$ & 120.42 \\
Lahore & $186.52(110.43-243.79)$ & $2.64 \pm 0.43$ & 32.91 & $<0.01$ & $-6.00 \pm 1.10$ & 73.43 \\
Rahim Yar Khan & $256.60(172.34-345.16)$ & $3.50 \pm 1.48$ & 67.50 & $<0.01$ & $-8.45 \pm 2.87$ & 101.02 \\
Jhang & $275.91(74.74-355.02)$ & $3.24 \pm 0.95$ & 47.26 & $<0.01$ & $-7.91 \pm 2.50$ & 108.62 \\
Gujranwala & $213.24(189.24-265.19)$ & $2.83 \pm 0.50$ & 86.26 & $<0.01$ & $-6.61 \pm 1.91$ & 83.92 \\
Laboratory & $2.54(2.34-2.75)$ & $2.41 \pm 0.10$ & 6.35 & 0.27 & $-0.98 \pm 0.07$ & - \\
\hline
\end{tabular}

LC: lethal concentration; FL: fiducial limits; RR: resistance ratio; ${ }^{a}$ RR = LC50-resistant population/LC50-susceptible population.

\subsection{Resistance in T. granarium}

As in the previous species, all examined populations of T. granarium were found to be resistant to phosphine in relation to the laboratory-susceptible population. Probit analysis revealed that the $\mathrm{LC}_{50}$ for the laboratory population was $2.01 \mathrm{ppm}$. The Layyah T. granarium population was the most resistant, having $\mathrm{LC}_{50}$ at $169.99 \mathrm{ppm}$, i.e., it was 84.57 -fold more resistant than the laboratory population, followed by the Jhang, Bahawalpur and Multan populations, which had $\mathrm{LC}_{50}$ values of $145.23,131.11$ and $127.21 \mathrm{ppm}$, i.e., they were $72.25-$, 65.22- and 63.28-fold more resistant than the laboratory population, respectively (Table 4). 
Table 4. Probit analysis of mortality for 10 field-collected populations and a laboratory-susceptible population of Trogoderma granarium adults after $20 \mathrm{~h}$ of exposure to phosphine. In all cases DF $=5$.

\begin{tabular}{ccccccc}
\hline Region & LC $_{\mathbf{5 0}}(\mathbf{p p m}) \mathbf{9 5} \mathbf{9} \mathbf{~ F L}$ & Slope & Chi-Square & $p$ & Intercept $^{\mathbf{p}}$ & $\mathbf{R R}^{\mathbf{a}}$ \\
\hline Sargodha & $86.29(77.48-94.96)$ & $2.15 \pm 0.09$ & 6.39 & 0.26 & $-4.16 \pm 0.22$ & 42.93 \\
Multan & $127.21(115.25-139.05)$ & $1.95 \pm 0.09$ & 4.48 & 0.48 & $-4.11 \pm 0.22$ & 63.28 \\
Faisalabad & $100.35(69.68-129.76)$ & $1.75 \pm 0.18$ & 20.01 & $<0.01$ & $-3.51 \pm 0.42$ & 49.92 \\
Bahawalpur & $131.11(100.44-161.00)$ & $2.06 \pm 0.18$ & 18.18 & $<0.01$ & $-4.36 \pm 0.44$ & 65.22 \\
Rawalpindi & $75.47(66.65-84.12)$ & $1.96 \pm 0.09$ & 4.17 & 0.52 & $-3.69 \pm 0.22$ & 37.54 \\
Layyah & $169.99(127.74-212.78)$ & $1.98 \pm 0.21$ & 25.57 & $<0.01$ & $-4.42 \pm 0.51$ & 84.57 \\
Lahore & $74.50(19.81-126.43)$ & $1.38 \pm 0.28$ & 53.47 & $<0.01$ & $-2.59 \pm 0.67$ & 37.06 \\
Rahim Yar Khan & $117.76(99.48-135.73)$ & $2.40 \pm 0.14$ & 11.00 & 0.05 & $-4.97 \pm 0.34$ & 58.58 \\
Jhang & $145.23(103.79-185.91)$ & $1.89 \pm 0.21$ & 25.01 & $<0.01$ & $-4.10 \pm 0.50$ & 72.25 \\
Gujranwala & $109.19(100.36-117.92)$ & $2.48 \pm 0.10$ & 5.71 & 0.33 & $-5.05 \pm 0.23$ & 54.32 \\
Laboratory & $2.01(1.82-2.21)$ & $2.20 \pm 0.18$ & 7.81 & 0.16 & $-0.67 \pm 0.17$ & - \\
\hline
\end{tabular}

LC: lethal concentration; FL: fiducial limits; RR: resistance ratio; ${ }^{a}$ RR = LC50-resistant population/LC50-susceptible population.

\section{Discussion}

Knowledge of the resistance status among different insect pests is an important issue because it influences the community to alternate the use of chemical insecticides with others that demonstrate a different mode of action [23]. During the present study, 10 out of 10 populations of $R$. dominica, T. castaneum, S. granarius and T. granarium, originating from different geographical localities, were found to be resistant to phosphine. In previous studies, Alam et al. [57] and Ahmad et al. [58] reported phosphine resistance in T. castaneum, $R$. dominica, S. oryzae and T. granarium populations collected from two remote areas of Pakistan. Surprisingly, both publications reported almost identical data for all tested insect populations. Therefore, the results of both studies should be taken into consideration with extreme caution. However our study reports phosphine resistance in insect pests from numerous areas in Pakistan, where there is no published literature available. We also report phosphine resistance in S. granarius for the first time in the country. In the USA, 4 out of 11 populations of T. castaneum collected from California were found to be resistant to phosphine, with resistance frequencies ranging between 42 and 100\% [59]. Opit et al. [26] determined that eight out of nine $(89 \%)$ and five out of five $(100 \%)$ populations of $T$. castaneum and $R$. dominica from ten different counties of Oklahoma were found to be resistant to phosphine. Cato et al. [35] found that 12 out of 25 populations of $T$. castaneum collected from the USA and Canada were resistant to phosphine, with resistance frequencies ranging from $2-100 \%$. In Brazil, phosphine resistance was also recorded in all $22(100 \%)$ of the different populations of $S$. zeamais studied [60]. The occurrence of phosphine resistance might be due to the presence of a resistance gene in the population, and also by the selection pressure from phosphine application. The flight activity of adults and the shipment of commodities that contained insect pests with the resistant gene are held responsible for gene flow, increasing phosphine resistance [61].

Phosphine resistance at least 100 times higher than susceptible populations has been recorded in different continents including Africa, Asia, Australia and South America [25,62-71]. In Pakistan, Ahmedani et al. [51] recorded a 2.54-3.98-fold increase in resistance level in two populations of $T$. granarium, collected from two remote areas of the Rawalpindi district, compared with a susceptible population. The authors concluded that the historical application of phosphine gas in these locations could not explain the low level of phosphine resistance. However, in the present study, the observed resistance to phosphine is 84.57-fold higher in T. granarium. Although the sampled locations in our study are different from the aforementioned study, resistance to phosphine has increased with time. The trade of infested grains among areas that host storage facilities results in the spread of resistance genes among insects' populations, and consequently leads to the increased resistance in an area [35,61]. Opit et al. [26] reported $\mathrm{LC}_{99}$ at 377.49 and $3430.8 \mathrm{ppm}$ for resistant $T$. castaneum and $R$. dominica populations, respectively, from Oklahoma, which was much higher compared with Zettler and Cuperus [34], who determined 
their resistance levels 21 years before (i.e., 9.2 and $6.6 \mathrm{ppm}$ respectively). The different level of resistance ratios among different populations of the same species, as observed in this study, might be due to their genetic diversity [72,73] and distinct geographical areas [35]. The elevated frequency of phosphine applications in a given area is associated with low genetic diversities of stored-product coleopterans, compared with areas with less frequent applications of phosphine, due to the suppression of low frequency haplotypes $[74,75]$.

In Pakistan, different types of storage structures, including conventional house-type warehouses ("godowns"), hexagonal bins, binishells, bunkers, concrete/steel silos and temporary open storage ("ganjis"), are used to store wheat commodities. Conventional warehouses hold almost $70 \%$ of stored grains, followed by binishells at $13 \%$, hexagonal bins at $7 \%$, bunkers at $6 \%$ and concrete/steel silos at $4 \%$. More than $60 \%$ of wheat is stored in bags on outdoor mats and covered by polythene [76]. Phosphine is a common fumigant for treating grains and the overuse of a single fumigant, as well as underdosing, can be a cause of the emergence of resistance in stored-grain insect pests. The most resistant insect populations originated from the southern part of Pakistan (e.g., Layyah, Multan and Rahim Yar Khan) where very hot summers prevail. Nayak et al. [77] reported that warm temperatures favor the elevated population growth of insect pests that are associated with the appearance of strongly resistant populations. Furthermore, a number of additional factors might be responsible for the increase in resistance to phosphine, e.g., leaky storage structures that lead to underdosing of phosphine, no phosphine-concentration monitoring during fumigation, exclusive reliance upon a single type of fumigation, little or no focus on integrated pest management at the farm level and insect movement through the commodity trade $[12,25,33,78]$. The mechanism involved in phosphine resistance is that of resistant individuals receiving lower or overused phosphine gas, compared with susceptible ones [4,79-82].

Our findings determined different levels of phosphine resistance, weak and strong, among the tested species. Four populations (i.e., Lahore, Gujranwala, Rawalpindi and Rahim Yar Khan) of S. granarius presented weaker resistance compared with the other insect pest populations. In the current study, the most resistant population of $R$. dominica had $\mathrm{LC}_{50}$ at $360.90 \mathrm{ppm}$ after $20 \mathrm{~h}$, which equate to 7,218 ppm per h to kill the insect population. This gas concentration should be maintained under airtight conditions. However, it is not possible to retain such high concentrations of phosphine due to leaky and poor storage conditions in Pakistan. Thus, it is difficult to attain the required level of phosphine concentration, leading to resistance in insect pests. This is an issue that encourages the replacement of phosphine with alternative approaches for the sustainable management of stored-grain insect pests in Pakistan. For the first time Collins et al. [83] described different levels of phosphine resistance in insects and detected two levels of resistance in $R$. dominica, i.e., weak resistance, corresponding to a 23-fold increase, and strong resistance, corresponding to $>100$-fold increase. Similarly to our findings, Afful et al. [23] reported weak and strong resistance among populations of $R$. dominica originating from North America. The authors concluded that the low resistant population ranged between 5.2- to 9.5-fold higher resistance while the strong resistant population exhibited 100.2- to 595.9-fold higher resistance when compared with the susceptible population. Schlipalius et al. [72] elaborated that insects have a distinct weak resistant phenotype which is homozygous to the resistance alleles on gene locus (usually stated as rph1). However, the strong resistant phenotype requires the insect to be homozygous at rph1 as well as at the second locus for resistance (referred to as rph2), and the two loci work synergistically to indicate the strong resistant phenotype.

The phosphine concentrations obtained during our study were much higher than those recommended against $R$. dominica, T. castaneum, T. granarium and S. granarius. For instance, Opit et al. [26] found that LC 99 ranged between 377 and 3431 ppm against T. castaneum and $R$. dominica $72 \mathrm{~h}$ post-exposure period. Additionally, Gautam et al. [20] determined $\mathrm{LC}_{99}$ at 1030.7 ppm for killing the eggs of the most resistant population of $O$. surinamensis from the USA, compared with the 28.4 ppm required to kill the eggs of the susceptible 
laboratory population after $72 \mathrm{~h}$ of exposure interval. Considering the aforementioned issues, there are some management approaches that need to be adopted to overcome the phosphine resistance. An important step is to construct a "national-resistance-monitoring program" [61] by recording the occurrence of resistance in different stored-product insect species in different regions of Pakistan, according to Ahmedani et al. [51] and the current study. Next, the recommended phosphine concentrations should be revised on the basis of laboratory and field trials $[67,69]$. Other management tactics involve eradication of the resistant populations through extended exposure periods to phosphine, an increase in the concentration of phosphine, proper sealing of storage facilities, the replacement of old phosphine application equipment, enhancement of grain turning, application of grain protectants, sanitization of storage facilities, implementation of residual insecticides, monitoring of populations of pests through inspection and sampling, as well as the use of alternative gases (e.g., sulfuryl fluoride) [68,69,71].

\section{Conclusions}

Our study is the first comprehensive report on the detection of the level of phosphine resistance in 10 different populations of $R$. dominica, T. castaneum, T. granarium and S. granarius collected from geographically distinct districts of Pakistan. Our findings revealed that all tested species and populations are resistant to phosphine fumigation-therefore alternative management strategies should be pursued. We detected variable levels of phosphine resistance among the tested insect pests. The frequency and prevalence of resistant individuals indicate widespread insufficiency of fumigation practices and a high incidence of improperly sealed storage facilities. Thus, we recommend improvements in storage practices and structures, as well as the implementation of resistance-management programs. Furthermore, plans at the national level should be elaborated in order to moderate the resistance to phosphine-retaining this fumigant as a feasible stored-grain pest-management tool.

Author Contributions: Designed research, W.W.; methodology, W.W.; data curation, W.W. and M.U.; formal analysis, W.W. and M.U.; performed research, M.U.; writing-review and editing, W.W., N.G.K., M.U., S.G. and H.A.F.E.-S.; supervision, W.W.; funding acquisition, W.W. All authors have read and agreed to the published version of the manuscript.

Funding: This study was funded by the Agricultural Linkages Program CS-097, Pakistan Agricultural Research Council (ALP-PARC), Islamabad, Pakistan.

Institutional Review Board Statement: Not applicable.

Data Availability Statement: Data is contained within the article.

Acknowledgments: We are grateful to Paul Schliekelman (University of Georgia, Athens, GA, USA), Shaohui Wu and Xuelin Luo (statistical consultant) (University of Georgia, Tifton, GA, USA) and Muhammad Khalid Bashir (University of Agriculture, Faisalabad, Pakistan) for their suggestions and technical guidance in data analysis.

Conflicts of Interest: The authors declare no conflict of interest.

\section{References}

1. Arthur, F.H. Efficacy of combinations of methoprene and deltamethrin as long-term commodity protectants. Insects 2019, 10,50 . [CrossRef]

2. Phillips, T.W.; Thoms, E.M.; DeMark, J.; Walse, S. Fumigation. In Stored Product Protection; Hagstrum, D.W., Phillips, T.W., Cuperus, G., Eds.; Kansas State University: Manhattan, KS, USA, 2012; pp. 157-177.

3. Wijayaratne, L.K.W.; Rajapakse, R.H.S. Effects of spinosad on the heat tolerance and cold tolerance of Sitophilus oryzae L. (Coleoptera: Curculionidae) and Rhyzopertha dominica F. (Coleoptera: Bostrichidae). J. Stored Prod. Res. 2018, 77, 84-88. [CrossRef]

4. Opit, G.; Collins, P.J.; Daglish, G.J. Resistance management. In Stored Product Protection; Hagstrum, D.W., Phillips, T.W., Cuperus, G., Eds.; Kansas State University: Manhattan, KS, USA, 2012; pp. 143-155.

5. Pimentel, M.A.G.; Faroni, L.R.A.; Tótola, M.R.; Guedes, R.N.C. Phosphine resistance, respiration rate and fitness consequences in stored-product insects. Pest Manag. Sci. 2007, 63, 876-881. [CrossRef]

6. Rossi, E.; Cosimi, S.; Loni, A. Insecticide resistance in Italian populations of Tribolium flour beetles. Bull. Insectol. 2010, 63, 251-285. 
7. Daglish, G.J.; Nayak, M.K. Prevalence of resistance to deltamethrin in Rhyzopertha dominica (F.) in eastern Australia. J. Stored Prod. Res. 2018, 78, 45-49. [CrossRef]

8. Attia, M.A.; Wahba, T.F.; Shaarawy, N.; Moustafa, F.I.; Guedes, R.N.C.; Dewer, Y. Stored grain pest prevalence and insecticide resistance in Egyptian populations of the red flour beetle Tribolium castaneum (Herbst) and the rice weevil Sitophilus oryzae (L.). J. Stored Prod. Res. 2020, 87, 101611. [CrossRef]

9. Guedes, R.N.C.; Lima, J.O.G.; Santos, J.P.; Cruz, C.D. Inheritance of deltamethrin resistance in a Brazilian strain of maize weevil (Sitophilus zeamais Mots.). Int. J. Pest Manag. 1994, 40, 103-106. [CrossRef]

10. Guedes, R.N.C.; Lima, J.O.G.; Santos, J.P.; Cruz, C.D. Resistance to DDT and pyrethroids in Brazilian populations of Sitophilus zeamais Motsch. (Coleoptera: Curculionidae). J. Stored Prod. Res. 1995, 31, 145-150. [CrossRef]

11. Lorini, I.; Galley, D.J. Deltamethrin resistance in Rhyzopertha dominica (F.) (Coleoptera: Bostrichidae), a pest of stored grain in Brazil. J. Stored Prod. Res. 1999, 35, 37-45. [CrossRef]

12. Fragoso, D.B.; Guedes, R.N.C.; Rezende, S.T. Glutathione S-transferase detoxification as a potential pyrethroid resistance mechanism in the maize weevil, Sitophilus zeamais. Entomol. Exp. Appl. 2003, 109, 21-29. [CrossRef]

13. Ribeiro, B.M.; Guedes, R.N.C.; Oliveira, E.E.; Santos, J.P. Insecticide resistance and synergism in Brazilian populations of Sitophilus zeamais (Coleoptera: Curculionidae). J. Stored Prod. Res. 2003, 39, 21-31. [CrossRef]

14. Fragoso, D.B.; Guedes, R.N.C.; Peternelli, L.A. Developmental rates and population growth of insecticide resistant and susceptible populations of Sitophilus zeamais. J. Stored Prod. Res. 2005, 41, 271-281. [CrossRef]

15. Perez Mendoza, J. Survey of insecticide resistance in Mexican populations of maize weevil, Sitophilus zeamais Motschulsky (Coleoptera: Curculionidae). J. Stored Prod. Res. 1999, 35, 107-115. [CrossRef]

16. Beckett, S.J.; Evans, D.E.; Morton, R. A comparison of the demographies of pesticide susceptible and resistant strains of Oryzaephilus surinamensis (L.) (Coleoptera: Silvanidae) on kibbled wheat. J. Stored Prod. Res. 1996, 32, 141-151. [CrossRef]

17. Bell, C.H. Fumigation in the 21st century. Crop Prot. 2000, 19, 563-569. [CrossRef]

18. Chaudhry, M.Q. Phoshine resistance: A growing threat to an ideal fumigant. Pestic. Outlook 2000, 11, 88-91. [CrossRef]

19. Phillips, T.W.; Throne, J.E. Biorational approaches to managing stored-product insects. Annu. Rev. Entomol. 2010, 55, $375-397$. [CrossRef]

20. Kaur, R.; Nayak, M.K. Developing effective fumigation protocols to manage strongly phosphine-resistant Cryptolestes ferrugineus (Stephens) (Coleoptera: Laemophloeidae). Pest Manag. Sci. 2015, 71, 1297-1302. [CrossRef]

21. Holloway, J.C.; Falk, M.G.; Emery, R.N.; Collins, P.J.; Nayak, M.K. Resistance to phosphine in Sitophilus oryzae in Australia: A national analysis of trends and frequencies over time and geographical spread. J. Stored Prod. Res. 2016, 69, 129-137. [CrossRef]

22. Nayak, M.K.; Daglish, G.J.; Phillips, T.W. Managing resistance to chemical treatments in stored products pests. Stewart Postharvest Rev. 2015, 11, 3 .

23. Afful, E.; Elliott, B.; Nayak, M.K.; Phillips, T.W. Phosphine resistance in North American field populations of the lesser grain borer, Rhyzopertha dominica (Coleoptera: Bostrichidae). J. Econ. Entomol. 2018, 111, 463-469. [CrossRef]

24. Champ, B.R.; Dyte, C.E. Report of the FAO Global Survey of Pesticide Susceptibility of Stored Grain Pests; Food and Agriculture Organization of the United Nations: Rome, Italy, 1976.

25. Lorini, I.; Collins, P.J.; Daglish, G.J.; Nayak, M.K.; Pavic, H. Detection and characterisation of strong resistance to phosphine in Brazilian Rhyzopertha dominica (F.) (Coleoptera: Bostrychidae). Pest Manag. Sci. 2007, 63, 358-364. [CrossRef]

26. Opit, G.P.; Phillips, T.W.; Aikins, M.J.; Hasan, M.M. Phosphine resistance in Tribolium castaneum and Rhyzopertha dominica from stored wheat in Oklahoma. J. Econ. Entomol. 2012, 105, 1107-1114. [CrossRef]

27. Nayak, M.K.; Holloway, J.C.; Emery, R.N.; Pavic, H.; Bartlet, J.; Collins, P.J. Strong resistance to phosphine in the rusty grain beetle, Cryptolestes ferrugineus (Stephens) (Coleoptera: Laemophloeidae): Its characterisation, a rapid assay for diagnosis and its distribution in Australia. Pest Manag. Sci. 2013, 69, 48-53. [CrossRef]

28. Nguyen, T.T.; Collins, P.J.; Ebert, P.R. Inheritance and characterization of strong resistance to phosphine in Sitophilus oryzae (L.). PLoS ONE 2015, 10, e0124335. [CrossRef]

29. Afful, E.; Tadesse, T.M.; Nayak, M.K.; Phillips, T.W. High-dose strategies for managing phosphine resistant populations of Rhyzopertha dominica (F.) (Coleoptera: Bostrichidae). Pest Manag. Sci. 2020, 76, 1683-1690. [CrossRef]

30. Afful, E.; Cato, A.; Nayak, M.K.; Phillips, T.W. A rapid assay for the detection of resistance to phosphine in the lesser grain borer, Rhyzopertha dominica (F.) (Coleoptera: Bostrichidae). J. Stored Prod. Res. 2021, 91, 101776. [CrossRef]

31. Chen, Z.; Schlipalius, D.; Opit, G.; Subramanyam, B.H.; Phillips, T.W. Diagnostic molecular markers for phosphine resistance in U.S. populations of Tribolium castaneum and Rhyzopertha dominica. PLoS ONE 2015, 10, e0121343. [CrossRef] [PubMed]

32. Kaur, R.; Subbarayalu, M.; Jagadeesan, R.; Daglish, G.J.; Nayak, M.K.; Naik, H.R.; Ramasamy, S.; Subramanian, C.; Ebert, P.R.; Schlipalius, D.I. Phosphine resistance in India is characterised by a dihydrolipoamide dehydrogenase variant that is otherwise unobserved in eukaryotes. Heredity 2015, 115, 188-194. [CrossRef]

33. Gautam, S.G.; Opit, G.P.; Konemann, C.; Shakya, K.; Hosoda, E. Phosphine resistance in saw-toothed grain beetle, Oryzaephilus surinamensis in the United States. J. Stored Prod. Res. 2020, 89, 101690. [CrossRef]

34. Zettler, J.L. Influence of resistance of future fumigation technology. In Proceedings of the International Conference on Controlled Atmosphere and Fumigation in Stored Products, Nicosia, Cyprus, 21-26 April 1996; Donahaye, E.J., Navarro, S., Varnava, A., Eds.; Printco Ltd.: Nicosia, Cyprus, 1997; pp. 445-454. 
35. Cato, A.J.; Elliott, B.; Nayak, M.K.; Phillips, T.W. Geographic variation in phosphine resistance among North American populations of the red flour beetle. J. Econ. Entomol. 2017, 110, 1359-1365. [CrossRef] [PubMed]

36. Hill, D.S. Pests of Stored Foodstuffs and Their Control; Kluwer Academic Publishers: New York, NY, USA, 2003.

37. Rees, D. Insects of Stored Products; Manson Publishing: London, UK, 2004.

38. Mahroof, R.M.; Hagstrum, D.W. Biology, behavior, and ecology of insects in processed commodities. In Stored Product Protection; Hagstrum, D.W., Phillips, T.W., Cuperus, G., Eds.; Kansas State University: Manhattan, KS, USA, 2012; pp. 33-44.

39. Mason, L.J.; McDonough, M. Biology, behavior, and ecology of stored grain and legume insects. In Stored Product Protection; Hagstrum, D.W., Phillips, T.W., Cuperus, G., Eds.; Kansas State University: Manhattan, KS, USA, 2012; pp. 7-20.

40. Hagstrum, D.W.; Klejdysz, T.; Subramanyam, B.H.; Nawrot, J. Atlas of Stored-Product Insects and Mites; AACC International: St. Paul, MN, USA, 2013.

41. Lowe, S.; Brone, M.; Boudjelas, S.; Poorter De, M. 100 of the World's Worst Invasive Alien Species. A Selection from the Global Invasive Species Database; Hollands Printing Ltd.: Auckland, New Zealand, 2000.

42. Kavallieratos, N.G.; Athanassiou, C.G.; Guedes, R.N.C.; Drempela, J.D.; Boukouvala, M.C. Invader competition with local competitors: Displacement or co-existence among the invasive khapra beetle, Trogoderma granarium Everts (Coleoptera: Dermestidae), and two other major stored-grain beetles? Front. Plant Sci. 2017, 8, 1837. [CrossRef]

43. Kavallieratos, N.G.; Karagianni, E.S.; Papanikolaou, N.E. Life history of Trogoderma granarium Everts (Coleoptera: Dermestidae) on peeled barley, peeled oats and triticale. J. Stored Prod. Res. 2019, 84, 101515. [CrossRef]

44. Kavallieratos, N.G.; Athanassiou, C.G.; Boukouvala, M.C.; Tsekos, G.T. Influence of different non-grain commodities on the population growth of Trogoderma granarium Everts (Coleoptera: Dermestidae). J. Stored Prod. Res. 2019, 81, 31-39. [CrossRef]

45. Myers, S.W.; Hagstrum, D.W. Quarantine. In Stored Product Protection; Hagstrum, D.W., Phillips, T.W., Cuperus, G., Eds.; Kansas State University: Manhattan, KS, USA, 2012; pp. 297-304.

46. EPPO (European and Mediterranean Plant Protection Organization). EPPO Global Data Base. Trogoderma granarium. Available online: https:/ /gd.eppo.int/taxon/TROGGA (accessed on 27 November 2020).

47. Athanassiou, C.G.; Kavallieratos, N.G.; Boukouvala, M.C. Population growth of the khapra beetle, Trogoderma granarium Everts (Coleoptera: Dermestidae) on different commodities. J. Stored Prod. Res. 2016, 69, 72-77. [CrossRef]

48. Islam, M.S.; Shahjahan, M.; Motaleb, M.A.; Hye, M.A. Laboratory evaluation of some indigenous plant extracts against granary weevil, Sitophilus granarius L. (Coleoptera: Curculionidae). Pak. J. Biol. Sci. 2002, 5, 763-766.

49. Wakil, W.; Schmitt, T. Field trials on the efficacy of Beauveria bassiana, diatomaceous earth and imidacloprid for the protection of wheat grains from four major stored grain insect pests. J. Stored Prod. Res. 2015, 64, 160-167. [CrossRef]

50. Honey, S.F.; Bajwa, B.; Mazhar, M.S.; Wakil, W. Trogoderma granarium (Everts) (Coleoptera: Dermestidae), an alarming threat to rice supply chain of Pakistan. Int. J. Entomol. Res. 2017, 5, 23-31.

51. Ahmedani, M.S.; Shaheen, N.; Ahmedani, M.Y.; Aslam, M. Status of phosphine resistance in khapra beetle, Trogoderma granarium (Everts) strains collected from remote villages of Rawalpindi district. Pak. Entomol. 2007, 29, 95-102.

52. Wakil, W.; Ghazanfar, M.U.; Yasin, M. Naturally occurring entomopathogenic fungi Infecting stored grain insect species in Punjab, Pakistan. J. Insect Sci 2014, 14, 182. [CrossRef]

53. FAO (Food and Agriculture Organization of the United Nations). Recommended methods for the detection and measurement of resistance of agricultural pests to pesticides. Tentative method for adults of some major pest species of stored cereals, with methyl bromide and phosphine. FAO method no. 16. Plant Protect. Bull. 1975, 23, 12-25.

54. Jagadeesan, R.; Collins, P.J.; Daglish, G.J.; Ebert, P.R.; Schlipalius, D.I. Phosphine resistance in the rust red flour beetle, Tribolium castaneum (Coleoptera: Tenebrionidae): Inheritance, gene interactions and fitness costs. PLoS ONE 2012, 7, e31582. [CrossRef] [PubMed]

55. Abbott, W.S. A method of computing the effectiveness of an insecticide. J. Econ. Entomol. 1925, 18, 265-267. [CrossRef]

56. SAS Institute Inc. SAS/ETS ${ }^{\circledR} 9.1$ User's Guide; SAS Institute Inc.: Cary, NC, USA, 2004.

57. Alam, M.S.; Shaukat, S.S.; Ahmed, M.; Iqbal, S.; Ahmad, A. A survey of resistance to phosphine in some coleopterous pests of stored wheat and rice grain in Pakistan. Pak. J. Biol. Sci. 1999, 2, 623-626. [CrossRef]

58. Ali, Q.M.; Abbas, M.; Arif, S. Monitoring of resistance against phosphine in stored grain insect pests in Sindh. Middle East J. Sci. Res. 2013, 16, 1501-1507.

59. Gautam, S.G.; Opit, G.P.; Hosoda, E. Phosphine resistance in adult and immature life stages of Tribolium castaneum (Coleoptera: Tenebrionidae) and Plodia interpunctella (Lepidoptera: Pyralidae) populations in California. J. Econ. Entomol. 2016, 109, 2525-2533. [CrossRef]

60. Pimentel, M.A.G.; Faroni, L.R.D.A.; Guedes, R.N.C.; Sousa, A.H.; Tótola, M.R. Phosphine resistance in Brazilian populations of Sitophilus zeamais Motschulsky (Coleoptera: Curculionidae). J. Stored Prod. Res. 2009, 45, 71-74. [CrossRef]

61. Hernandez Nopsa, J.F.; Daglish, G.J.; Hagstrum, D.W.; Leslie, J.F.; Phillips, T.W.; Scoglio, C.; Thomas Sharma, S.; Walter, G.H.; Garrett, K.A. Ecological networks in stored grain: Key postharvest nodes for emerging pests, pathogens, and mycotoxins. BioScience 2015, 65, 985-1002. [CrossRef]

62. Mills, K.A. Resistance to the fumigant hydrogen phosphide in some stored-product species associated with repeated inadequate treatments. Mitt. Dtsch. Ges. Allg. Angew. Entomol. 1983, 4, 98-101.

63. Tyler, P.S.; Taylor, R.W.; Rees, D.P. Insect resistance to phosphine fumigation in food warehouses in Bangladesh. Int. Pest Control 1983, 25, 10-13. 
64. Taylor, R.W.D.; Halliday, D. The geographical spread of resistance to phosphine by coleopterous pests of stored products. In Proceedings of the British Crop Protection Conference, Pests and Diseases, Brighton Metropole, UK, 17-20 November 1986; British Crop Protection Council: Thornton Heath, UK, 1986; pp. 607-613.

65. Taylor, R.W.D. Phosphine-A major fumigant at risk. Int. Pest Control 1989, 31, 10-14.

66. Zettler, L.J.; Cuperus, G.W. Pesticide resistance in Tribolium castaneum (Coleoptera: Tenebrionidae) and Rhyzopertha dominica (Coleoptera: Bostrichidae) in wheat. J. Econ. Entomol. 1990, 83, 1677-1681. [CrossRef]

67. Sayaboc, P.D.; Gibe, A.J.G.; Caliboso, F.M. Resistance of Rhizopertha dominica (F.) (Coleoptera: Bostrychidae) to phosphine in the Philippines. Philipp. Entomol. 1998, 12, 91-95.

68. Collins, P.J.; Daglish, G.J.; Nayak, M.K.; Ebert, P.R.; Schlipalius, D.; Chen, W.; Pavic, H.; Lambkin, T.M.; Kopittke, R.; Bridgeman, B.W. Combating resistance to phosphine in Australia. In Proceedings of the International Conference on Controlled Atmosphere and Fumigation in Stored Products, Fresno, CA, USA, 29 October-3 November 2000; Donahaye, E.J., Navarro, S., Leesch, J.G., Eds.; Executive Printing Services: Clovis, CA, USA, 2001; pp. 593-607.

69. Nayak, M.; Holloway, J.; Pavic, H.; Head, M.; Reid, R.; Collins, P. Developing strategies to manage highly phosphine resistant populations of flat grain beetles in large bulk storages in Australia. In Proceedings of the 10th International Working Conference on Stored-Product Protection, Estoril, Portugal, 27 June-2 July; Carvalho, M.O., Fields, P.G., Adler, C.S., Arthur, F.H., Athanassiou, C.G., Campbell, J.F., Fleurat Lessard, F., Flinn, P.W., Hodges, R.J., Isikber, A.A., et al., Eds.; Julius Kühn Institut: Berlin, Germany, 2010; pp. 396-401.

70. Pimentel, M.A.G.; Farroni, L.R.D.A.; da Silva, F.H.; Batista, M.D.; Guedes, R.N.C. Spread of phosphine resistance among Brazilian populations of three species of stored product insects. Neotrop. Entomol. 2010, 39, 101-107. [CrossRef]

71. Emery, R.N.; Nayak, M.K.; Holloway, J.C. Lessons learned from phosphine resistance monitoring in Australia. Stewart Postharvest Rev. 2011, 3, 6 .

72. Schlipalius, D.I.; Valmas, N.; Tuck, A.G.; Jagadeesan, R.; Ma, L.; Kaur, R.; Goldinger, A.; Anderson, C.; Kuang, J.; Zuryn, S.; et al. A core metabolic enzyme mediates resistance to phosphine gas. Science 2012, 338, 807-810. [CrossRef]

73. Nguyen, T.T.; Collins, P.J.; Duong, T.M.; Schlipalius, D.I.; Ebert, P.R. Genetic conservation of phosphine resistance in the rice weevil Sitophilus oryzae (L.). J. Hered. 2016, 107, 228-237. [CrossRef]

74. McCulloch, G.A.; Mohankumar, S.; Subramaniam, S.; Sonai Rajan, T.; Rahul, C.; Surendran, R.; Gaurav, R.; Chandrasekaran, S.; Daglish, G.J.; Walter, G.H. Contrasting patterns of phylogeographic structuring in two key beetle pests of stored grain in India and Australia. J. Pest Sci. 2019, 92, 1249-1259. [CrossRef]

75. Thangaraj, S.R.; McCulloch, G.; Subtharishi, S.; Chandel, R.K.; Debnath, S.; Subramaniam, C.; Walter, G.H.; Subbarayalu, M. Genetic diversity and its geographic structure in Sitophilus oryzae (Coleoptera: Curculionidae) across India-Implications for managing phosphine resistance. J. Stored Prod. Res. 2019, 84, 101512. [CrossRef]

76. Prikhodko, D.; Zrilyi, O. Pakistan. Review of the Wheat Sector and Grain Storage Issues; Food and Agriculture Organization of the United Nations (FAO): Rome, Italy, 2013.

77. Nayak, M.K.; Falk, M.G.; Emery, R.N.; Collins, P.J.; Holloway, J.C. An analysis of trends, frequencies and factors influencing the development of resistance to phoshine in the red flour beetle Tribolium castaneum (Herbst) in Australia. J. Stored Prod. Res. 2017, 72, 35-48. [CrossRef]

78. Benhalima, H.; Chaudhry, M.Q.; Mills, K.A.; Price, N.R. Phosphine resistance in stored-product insects collected from various grain storage facilities in Morocco. J. Stored Prod. Res. 2004, 40, 241-249. [CrossRef]

79. Price, N.R. A comparison of the uptake and metabolism of ${ }^{32} \mathrm{P}$-radiolabelled phosphine in susceptible and resistant strains of the lesser grain borer (Rhyzopertha dominica). Comp. Biochem. Physiol. C Toxicol. Pharmacol. 1981, 69, 129-131. [CrossRef]

80. Price, N.R. Active exclusion of phosphine as a mechanism of resistance in Rhyzopertha dominica (F.) (Coleoptera: Bostrychidae). J. Stored Prod. Res. 1984, 20, 163-168. [CrossRef]

81. Chaudhry, M.Q.; Price, N.R. Insect mortality at doses of phosphine which produce equal uptake in susceptible and resistant strains of Rhyzopertha dominica (F.) (Coleoptera: Bostrychidae). J. Stored Prod. Res. 1990, 26, 101-107. [CrossRef]

82. Chaudhry, M.Q. A review of the mechanisms involved in the action of phosphine as an insecticide and phosphine resistance in stored-product insects. Pestic. Sci. 1997, 49, 213-228. [CrossRef]

83. Collins, P.J.; Emery, R.N.; Wallbank, B.E. Two decades of monitoring and managing phosphine resistance in Australia. In Proceedings of the 8th International Working Conference on Stored-Product Protection, York, UK, 22-26 July 2002; Credland, P.F., Armitage, D.M., Bell, C.H., Cogan, P.M., Highley, E., Eds.; CAB International: Wallingford, UK, 2003; pp. 570-575. 